\title{
POSTKOLONIALNO-AUTOCHTONICZNY PARADYGMAT BADAŃ SPOŁECZNYCH NAD WIELOKULTUROWOŚCIĄ W PERSPEKTYWIE PEDAGOGICZNEJ
}

Wykształcenie się i ugruntowanie nowego paradygmatu badawczego dobitnie potwierdza, że współczesne nauki społeczne (w tym pedagogika) korzystając z - niezbywalnej moim zdaniem - zasady paradygmatyczności i wieloparadygmatyczności, a także przeczą postulatom czy nawet nietrafnym diagnozom o zaniechaniu myślenia i działania paradygmatycznego w społecznych badaniach empirycznych i studiach teoretycznych. Taki fakt jednoznacznie zaświadcza, że nie czas jeszcze żegnać paradygmaty w naukach społecznych, a w tym we współczesnej pedagogice. Utrzymanie zasady paradygmatyczności i wieloparadygmatyczności jako jednej z fundamentalnych w zapewnieniu minimum naukowości badań społecznych decyduje o ich rozwoju i zapewniać może nowe korzyści poznawcze z nich wynikające. Praktyczna realizacja zasady paradygmatyczności oznacza w tym przypadku stałe otwarcie na możliwość pojawienia się nowego paradygmatu, który w sposób swoisty, a czasami lepiej niż wszystkie dotychczasowe konstruować będzie warunki pogłębienia rozumienia badanej rzeczywistości społecznej. Wieloparadygmatyczność to z kolei warunek legitymizacji współistnienia i dialogu różnych paradygmatów, składających się na stale weryfikowaną i aktualizowaną mapę paradygmatyczną nauk społecznych i poszczególnych dyscyplin, przy czym pojawienie się i uznanie nowego paradygmatu zawsze prowadzi do rewizji paradygmatów wcześniej stosowanych oraz rekonfiguracji dotychczasowych map paradygmatycznych. Dynamika owych zmian nasila się w sytuacji wzmagania się i komplikowania przemian badanej rzeczywistości społecznej [zob. szerzej: Kubinowski 2013: 43-44].

Niniejsze opracowanie jest poświęcone prezentacji założeń jednego z takich nowych paradygmatów, który zmienił zasadniczo dotychczasowe mapy paradygmatyczne nauk społecznych uprawianych w różnych krajach 
poza Polską, który wykształcił się w rezultacie krytyk badań nad wielokulturowością w specyficznych kontekstach kultur autochtonicznych państw postkolonialnych, stąd jego nazwa „paradygmat postkolonialno-autochtoniczny”. Prezentacji tej towarzyszy jednak pytanie, czy ów paradygmat może być efektywnie poznawczo wykorzystany w badaniach społecznych nad wielokulturowością w Polsce, która przecież nie jest zaliczana do grupy byłych czy obecnych państw kolonialnych, a na dodatek należy do kategorii krajów względnie monokulturowych pod względem etnicznym. Próba odpowiedzi na tak postawione pytanie jest osadzona $\mathrm{w}$ perspektywie pedagogicznej badań społecznych, którą rozumiem jako zespolenie trzech poziomów dociekania do poznawania, rozumienia i interpretacji badanej rzeczywistości, a mianowicie: jej opisu (dokumentacji, analizy, interpretacji), wartościowania humanistycznego oraz ujmowania owego opisu i wartościowania z punktu widzenia potencjalności człowieka [zob. szerzej: Kubinowski 2008: 49-53]. Tak rozumiana perspektywa pedagogiczna zasadniczo wyróżnia pedagogikę jako dyscyplinę naukową pośród innych nauk społecznych, a także określa możliwość swoistego - bo pedagogicznego - badania i studiowania różnych zjawisk społecznych, kulturowych, osobowych i innych.

Marilyn Lichtman - amerykańska, feministyczna, jakościowa badaczka edukacji - tak tłumaczy wyraźnie zauważalny wzrost zainteresowania uprawianiem badań jakościowych w naukach społecznych, w tym pedagogicznych, począwszy od lat dziewięćdziesiątych XX wieku na całym świecie:

(...) otwarcie pola badań edukacyjnych dla kobiet i osób o różnych kolorach skóry doprowadziło do alternatywnych uwrażliwień i alternatywnych głosów. Nigdy już później badania ilościowe (rozwinięte przez białych mężczyzn z Europy) nie pozostawały jedynym wyborem spośród metod badawczych; inne sposoby poznawania mogły uzyskiwać pełną legitymizację [Lichtman 2006: XII].

Odnosząc się wprost do tezy M. Lichtman, należy jednak zauważyć, że to również biali mężczyźni z Europy przyczynili się wydatnie do zmian paradygmatycznych w uprawianiu badań społecznych, jakie dokonały się na początku XX wieku w antropologii kulturowej i socjologii, o czym mogą 
świadczyć chociażby przełomowe koncepcje metodologiczne Bronisława Malinowskiego i Floriana Znanieckiego. Zwiastowały one to wszystko, co „rozkwitło” w pełnej krasie na przełomie XX i XXI wieku w postaci kreatywności różnorodnych metodologii jakościowych w naukach społecznych na całym świecie.

Przytoczona wyżej konstatacja M. Lichtman wyraziście mogła zamanifestować się dopiero w świecie postkolonialnej Akademii w Stanach Zjednoczonych, w której do głosu dochodzili, a czasem wręcz dominowali badacze i badaczki pochodzący z różnych krajów pozaeuropejskich i pozapółnocnoamerykańskich, reprezentujący różne grupy etniczne, rasowe, mniejszościowe i inne. Osoby te przeważnie przyjeżdżały do USA i Europy na studia uniwersyteckie, korzystając ze stypendialnego wsparcia, wdrażając się w wiedzę i doświadczenie $\mathrm{z}$ zakresu wybranego obszaru nauki, a następnie uzyskując względną samodzielność naukową w tym świecie podejmowały próby przemycania do niego swoich idei, wywodzących się z ich rdzennych, autochtonicznych tradycji kulturowych. W sposób szczególny wpłynęły przede wszystkim na przeformułowanie dotychczasowych modeli uprawiania badań społecznych nad wielokulturowością współczesnego świata, choć nie tylko.

Jedną z takich czarnoskórych studentek uniwersytetów amerykańskich była Bagele Chilisa - dziś doktor nauk społecznych w zakresie edukacji, profesor Uniwersytetu Botswany. W 2012 roku opublikowała w Stanach Zjednoczonych monografię metodologiczną zatytułowaną Indigenous research methodologies, która stanowi - moim zdaniem - najpełniejszą i najbardziej kompetentną, jak dotąd, prezentację istoty, metodyki i egzemplifikacji kolonialno-autochtonicznego paradygmatu badań społecznych, stąd stanowi zasadniczą podstawę jego krótkiej charakterystyki w niniejszym opracowaniu.

Niezmiernie istotna jest w tym kontekście biografia badaczki. Bagele Chilisa urodziła się w małej wiosce Nshakashogwe w Botswanie, byłej brytyjskiej kolonii w południowej Afryce. Jej rodzice byli rolnikami i ciężko pracowali, aby móc opłacić jej szkolną edukację. Ojciec wdrażał ją - jak sama wspomina - w rozumienie dekolonizacji umysłu, choć nigdy tego tak nie nazywał. Uświadamiał jej jednocześnie sens i znaczenie tożsamości kulturowej w życiu każdego człowieka. W szkole średniej postanowiła przyjąć chrzest w Kościele rzymskokatolickim i wymagano od niej przyjęcia imienia chrześcijańskiego w języku angielskim. Jednak jej rodzice nie wyrazili na to zgody, gdyż zmiana imienia kogokolwiek z rodziny lub lokalnej społeczności przerywa natychmiast logiczny łańcuch powiązań krew- 
niaczych i etnicznych, gdyż są one odzwierciedlone wprost w autochtonicznych imionach. Odbyła studia wyższe w Uniwersytecie Pittsburgha w Stanach Zjednoczonych, tu także uzyskała doktorat. Od przeszło 20 lat prowadzi badania nad opresjonowaniem i dyskryminacją ze względu na płeć, rasę, etniczność, niepełnosprawność, orientację seksualną czy klasę społeczną, stosując metodologię „uwrażliwioną kulturowo”. Realizuje projekty badawcze w południowej i wschodniej Afryce we współpracy z naukowcami z Wielkiej Brytanii i USA, próbując kreować nowe synergiczno-partycypacyjne rozwiązania metodologiczne, włączające wiedzę i kulturę ludu, z którego się wywodzi. Oto, jak opisała źródła tych rozwiązań:

W trakcie mojej badawczej podróży zauważyłam, że operowałam dwoma systemami wiedzy, jednym rezonującym z moimi badanymi i drugim - akademickim, wywodzącym się z dyscyplin naukowych Zachodu. Przetrwanie nieakademickiego systemu wiedzy badanych zainspirowało mnie do napisania tej książki [Chilisa 2012: XX].

Postkolonialno-autochtoniczny paradygmat badań społecznych w ujęciu B. Chilisy - stanowi synergię i transgresję trzech innych, wcześniejszych paradygmatów stosowanych w naukach społecznych: teorii krytycznej, konstruktywistycznego i partycypacyjnego.

Autorka odwołuje się przy tym do znanej typologii paradygmatów badawczych w naukach społecznych w ujęciu Yvonny S. Lincoln i Egona G. Guby - jakościowych badaczy edukacji. Wyróżnili oni bowiem następujące zasadnicze paradygmaty: pozytywistyczny, postpozytywistyczny, teorii krytycznej (i pokrewne), konstruktywistyczny, partycypacyjny, szczegółowo charakteryzując ich aksjomaty w odniesieniu do przyjętych wymiarów - ontologicznego, epistemologicznego, metodologicznego, aksjologicznego i innych [Lincoln, Guba 200: 168-173].

W paradygmacie postkolonialno-autochtonicznym jest mocno eksploatowany potencjał metodologiczny teorii krytycznej, w szczególności skupiony na demaskowaniu i krytyce wszelkich przejawów kolonizacji umysłu oraz pedagogicznym wdrażaniu w życie społeczne opresjonowanych myślenia i działania dekolonizacyjnego. Chilisa nie tylko uzasadniła błędność i szkodliwość stosowania podejść badawczych rodem z kolonializmu 
w odniesieniu do społeczności autochtonicznych w byłych koloniach, ale na przykładzie problemu rozprzestrzeniania się HIV/AIDS w Afryce wykazała w swojej książce nieadekwatność badania ankietowego typowego dla paradygmatu pozytywistycznego stosowanego przez badaczy zachodnich, co prowadzi do jego empirycznego niezrozumienia i w rezultacie niemożności praktycznego rozwiązania. Jednocześnie przez badania własne udowodniła niezbędność posłużenia się w tym przypadku bezpośrednimi odwołaniami do autochtonicznego systemu wiedzy w projektowaniu i realizowaniu badań terenowych.

Włączenie do opisywanego tu paradygmatu założeń konstruktywizmu społecznego oznacza przede wszystkim uwzględnienie autochtonicznego punktu widzenia w badaniu kultury i życia danej społeczności, bez którego nie można osiągnąć stanu pogłębionego rozumienia. Jednak w przypadku społecznych badań nad wielokulturowością niezbędne jest ponadto uwzględnienie innych, różnych perspektyw rozumienia tej samej rzeczywistości - zarówno przez Swoich, jak i Obcych/Innych kulturowo. (Re)konstruowane w ten sposób jej obrazy i przypisywane im znaczenia składają się na komplementarne poznanie danego problemu z uwzględnieniem różnych punktów widzenia.

I wreszcie, paradygmat partycypacyjny został w nowym paradygmacie wielorako wykorzystany zarówno $\mathrm{w}$ relacjach między autochtonicznym badaczem a jego badanymi z rodzimej społeczności, traktowanymi często jako współbadacze, jak i w relacjach między różnymi badaczami współpracującymi w ramach zgranego zespołu, głównie autochtonicznymi i pochodzącymi z innych grup etnicznych, kulturowych. Uczona w swojej praktyce naukowej starała się kreować zespoły badawcze złożone z przedstawicieli lokalnej społeczności afrykańskiej, siebie i jej podobnych badaczy autochtonicznych posiadających przygotowanie akademickie, oraz naukowców z innych krajów (często postkolonialnych), dla których badana kultura stanowi swoiste novum, gdyż różni się zasadniczo od ich własnej kultury. Warunkiem takiej współpracy badawczej jest jednak akceptacja przez wszystkich badaczy - zarówno autochtonicznych, jak i nieautochtonicznych - potrzeby niwelowania niekorzystnych konsekwencji kolonializmu we wzajemnych relacjach i poszukiwania kompromisowych rozwiązań na przyszłość.

$\mathrm{Z}$ uwagi na fakt, że badania społeczne prowadzone w duchu tego paradygmatu opierają się w dużej mierze na autochtonicznym systemie wiedzy, trudno sobie wyobrazić efektywne, a przy tym idiomatyczne stosowanie standaryzowanych formularzy na masową skalę i prowadzenie skompli- 
kowanych, korelacyjnych analiz statystycznych. Taki sposób docierania do wiedzy jest bowiem obcy kulturowo lokalnym społecznościom. Nie oznacza to, że w tych badaniach nie są wykorzystywane dane statystyczne. Dominującymi metodami badawczymi w paradygmacie postkolonialno-autochtonicznym są różnorodne, adekwatne, często bezpośrednio kreowane odmiany i techniki badań jakościowych.

Paradygmat postkolonialno-autochtoniczny zakłada także (jak to ma miejsce w paradygmacie teorii krytycznej) synergię poznawania i zmieniania rzeczywistości społecznej. Zatem, badanie jest jednocześnie impulsem do pozytywnej zmiany, rozumianej jako wzmocnienie podmiotowości i tożsamości społeczności autochtonicznej w kontekście nowego ładu postkolonialnego, ale z uwzględnieniem aktualnej, globalnej sytuacji kulturowej oraz nieuchronnych przemian cywilizacyjnych. Jest to zatem poszukiwanie mądrego kompromisu między kontynuowaniem a zrewidowaniem własnych tradycji kulturowych przez autochtonów, w tym odejściem od ich barbarzyńskich, sprzecznych z powszechnymi prawami człowieka, elementów, i tym samym adaptowanie niektórych wzorów życia społecznego krajów Zachodu z zachowaniem własnej odrębności i tożsamości. Otwartość na inne kultury, w tym na imigrantów z terenów byłych kolonii, nie może być jednocześnie nieograniczonym prawem i bezwzględną zasadą, gdyż może doprowadzić, jeśli będzie nadużywane, do niekorzystnych konsekwencji demograficznych, społecznych i kulturowych w krajach postkolonialnych. W paradygmacie postkolonialno-autochtonicznym, w szczególności na etapie interpretowania zidentyfikowanych i opisanych problemów społecznych, badacze/działacze starają się rozumieć te zależności i poszukiwać nowoczesnych rozwiązań kompromisowych.

Mimo że opisywany tu paradygmat wykształcił się i ugruntował w badaniach społecznych w kontekstach postkolonialnych w sensie kulturowym, etnicznym, to jego twórcy i realizatorzy dostrzegają potencjał efektywnego wykorzystania jego założeń w rozpoznawaniu problemów wykraczających poza ten obszar, ale odnoszących się do analogicznych relacji międzyludzkich opartych na dominacji i opresjonowaniu, a także nowych formach kolonizowania umysłów ludzkich na gruncie polityki, gospodarki, edukacji, komunikacji społecznej, religii, rodziny, mediów masowych, nauki, sztuki.

Wróćmy teraz do pytania sformułowanego w części wstępnej, a dotyczącego potencjalnej użyteczności postkolonialno-autochtonicznego paradygmatu badań społecznych nad wielokulturowością w Polsce. Wydaje mi się, że w jego prymarnym wariancie, opisanym szczegółowo przez B. Chilisę trudno byłoby znaleźć taki fragment rzeczywistości społecznej, który 
dałoby się wpisać w ten model poznawczy, chociażby ze względu na fakt, że Polska jako państwo nie posiadała i nie posiada kolonii w sensie terytorialnym. Jednak w jego wariancie odpowiednio zmodyfikowanym, a dającym się zastosować w badaniu różnych sytuacji wielokulturowości, już takie zastosowania można byłoby próbować przekonująco uzasadniać. Nie znam projektu badawczego zrealizowanego w Polsce i w odniesieniu do problemów wielokulturowości w naszym kraju, w którym zastosowany został paradygmat postkolonialno-autochtoniczny. Spróbuję jednak rozważyć jego potencjał na przykładzie zakończonych pomyślnie badań z moim udziałem, mimo że wykorzystano w nich tylko jego niektóre elementy w ramach podejścia interpretatywnego.

We wrześniu 2013 roku został pomyślnie zakończony przewód doktorski Karoliny Sobot, która pod moim kierunkiem i w ramach grantu promotorskiego Ministerstwa Nauki i Szkolnictwa Wyższego przygotowała rozprawę opartą na zaawansowanym projekcie badawczym zatytułowanym Kulturowe uwarunkowania postaw Romów wobec obowiązku szkolnego [Sobot 2013]. Nie będę w tym miejscu referował ani koncepcji tych badań, ani ich rezultatów i wniosków praktycznych z nich wynikających, gdyż zostało to przedstawione szczegółowo przez autorkę i stanowi jej wkład w rozwój wiedzy w tym zakresie. Chciałbym jedynie wykorzystać ten materiał i doświadczenia wynikające z zakończonej już współpracy, aby zrekonstruować zmiany w moim myśleniu na temat Romów, ich kultury i edukacji w Polsce przez pryzmat założeń paradygmatu postkolonialno-autochtonicznego, chcąc w ten sposób przyczynić się do zachęcenia ewentualnych badaczy tej problematyki do rozważenia możliwości jego wykorzystania w przyszłych projektach badawczych z tego lub analogicznego zakresu. Wskażę tu tylko niektóre z wyłaniających się w trakcie badań pytań, wątpliwości, hipotez, prób konstruktywnych odpowiedzi.

Czy Polska jest krajem kolonialnym? W sensie terytorialnym - nie, ale w sensie mentalnym - może nim być w odniesieniu do kultury i edukacji mniejszości etnicznych zamieszkujących na jej obszarze. Czy Romowie w Polsce to autochtoni? W sensie ich proweniencji etnicznej i rasowejnie, ale gdy będziemy mieli na myśli klan Polskiej Romy, to uprawnione będzie przyjęcie takiej perspektywy traktowania jednej z mniejszości od dawna żyjącej na ziemiach polskich. Traktowanie Romów jako imigrantów albo jako autochtonów to dwie różne perspektywy rozumienia ich sytuacji kulturowej i edukacyjnej w Polsce.

Czy idea obowiązku szkolnego zawsze oznacza kulturowe dobro? Traktowanie obowiązkowej edukacji dzieci i młodzieży jako istotnej warto- 
ści cywilizacyjnej jest cechą państw należących do kręgu kultur europejskich i krajów postkolonialnych, stąd narzucanie jej wszystkim kulturom bez wyjątku jest przejawem barbarzyńskiego kolonizowania umysłów, szczególnie gdy dokonywana jest za pośrednictwem kultury i języka obcego. W tradycyjnej kulturze Romów edukacja szkolna nie była istotną wartością, szczególnie gdy egzekwowana jest w trybie bezwzględnie obowiązującym. W polskich szkołach Romowie realizują obowiązek szkolny za pośrednictwem kultury i języka polskiego a nie romskiego, czyli własnego. Jest to klasyczny przejaw kolonializmu kulturowego, tym bardziej, że jednocześnie nie prowadzi się lekcji z uwzględnieniem choćby elementów ich rdzennej kultury.

Czy tradycje kultury romskiej mają być przekazywane następnym pokoleniom i bezwzględnie szanowane przez społeczeństwo większościowe? Tradycje kulturowe określają tożsamość osobową i społeczną w decydującym stopniu, są więc traktowane jako wartość. Można o nich tylko pamiętać, a można je przekazywać i niezmiennie, bezrefleksyjnie praktykować. W przypadku kultury Romów pojawia się jednak istotny problem związany z tymi elementami ich tradycji, które wchodzą $\mathrm{w}$ kolizję $\mathrm{z}$ obowiązującym prawem w danym kraju oraz powszechnymi prawami człowieka. Przykładem może być kultywowany do dziś w społecznościach romskich mieszkających w Polsce zwyczaj zawierania małżeństwa przez porwanie. Uwzględniając założenia paradygmatu postkolonialno-autochtonicznego, interpretacja takiego zachowania może być tylko jedna. Współcześnie w Polsce jako kraju szanującym standardy demokratyczne i humanistyczne Romowie mogą kontynuować tylko te komponenty swojej dawnej tradycji, które nie są sprzeczne z obowiązującym w tym kraju prawem. Takie postawienie sprawy, oznacza rezygnację Romów z części swojej - niechlubnej tradycji, a to prowadzi niechybnie do zmian tożsamościowych. Nie niszczy jednak - jak to interpretują niektórzy z ich reprezentantów - całej kultury. Podobnie jest z edukacją. Część społeczności romskiej, szczególnie ta żyjąca dziś w związkach mieszanych (np. polsko-romskich), opowiada się za rewizją tradycyjnej hierarchii wartości, z dowartościowaniem edukacji jako warunku lepszej przyszłości, ale wraz z jej odpowiednim dostosowaniem do sytuacji kulturowej Romów i przede wszystkim wraz z odstąpieniem od wyciągania konsekwencji prawnych w stosunku do rodziców i opiekunów w przypadku zaniedbywania realizacji obowiązku szkolnego. Powiązanie obowiązku szkolnego z dotkliwymi sankcjami prawnymi jest niezrozumiałe nie tylko w kulturze romskiej. 
Czy jedyną drogą do emancypacji Romów jest edukacja? Takie stanowisko, prezentowane także przez niektórych przedstawicieli akademickiej pedagogiki/edukacji międzykulturowej w naszym kraju, jest przecież poglądem iście kolonialnym, szczególnie w sytuacji, gdy jest to edukacja polska dzieci romskich. Wydaje się, że dobrym rozwiązaniem w duchu analizowanego tu paradygmatu może okazać się poszerzanie palety alternatyw realizowania obowiązku szkolnego przez Romów i indywidualnego dostosowania go do możliwości i potrzeb konkretnej rodziny i danego ucznia. Obecność uczniów romskich w polskiej szkole podstawowej może i powinna być bardziej efektywnie wykorzystywana także w edukacji uczniów polskich i innych, o ile do niej uczęszczają. Rom w polskiej szkole jako kłopot czy jako dar - oto dwie różne perspektywy ustosunkowania się do tej samej rzeczywistości. Dzielenie się wartościami własnej kultury, o ile mają charakter konstruktywny, jest istotnym momentem sytuacji wychowawczych przygotowujących do (współ)życia w społeczeństwach wielokulturowych.

Jak docierać do pogłębionego rozumienia aktualnej sytuacji Romów w Polsce? To bariera trudna do pokonania przez badaczy nieautochtonicznych. W przypadku omawianego tu doktoratu efektywnym rozwiązaniem okazało się nawiązanie współpracy badawczej z miejscowym asystentem edukacji romskiej, który pełniąc rolę odźwiernego, przyczynił się do pokonywania przez polską badaczkę kolejnych przeszkód w dochodzeniu do wiedzy i rozwiązywaniu postawionych i identyfikowanych emergentnie problemów społecznych powiązanych z realizacją obowiązkowej edukacji przez Romów. Asystent - zgodnie z założeniami paradygmatu partycypacyjnego - stał się w pewnym sensie współbadaczem, choć i jego perspektywa rozumienia badanej rzeczywistości była swoista. Jednak dopiero złożenie tych różnych punktów widzenia pozwalało na poszukiwanie możliwości odzwierciedlenia i interpretacji złożonego, niejednoznacznego obrazu kulturowych czynników warunkujących szkolną edukację Romów w naszym kraju, na przykładzie jednej z lokalnych społeczności.

Jerzy Nikitorowicz, odwołując się do przykładów z historii i współczesności wielokulturowej Europy, przestrzega jednocześnie przed skrajnością dbania wyłącznie o przywileje mniejszości i w konsekwencji narażania się na zwiększenie kosztów społecznych ponoszonych przez większość:

„Wykreowana w krajach Europy Zachodniej idea relatywizmu kulturowego i poprawności politycznej w efekcie prowadziła ku wykluczaniu tożsamościowemu i marginalizacji nie tylko imigrantów, ale także obywateli kraju ich przyjmującego. Stało się tak za sprawą poszerzenia zakresu praw dla imigran- 
tów na prawa grupowe, ale nie zrobiono nic, aby te grupy mogły utożsamiać się z państwem. Sprowadzano od lat 60. i 70. XX wieku ludność z krajów, które wcześniej były koloniami, nie obejmując ich żadnymi programami adaptacyjnymi, nie określając praw i obowiązków innowierców, czy form kultywowania własnej religii i zasad funkcjonowania w nowych warunkach. Obok oficjalnej - niekonsekwentnie prowadzonej - polityki wyrosła nieoficjalna, żywiołowa. Obok meczetów powstawały fundamentalistyczne grupy religijne. Nie rozwiązano tego problemu, wskazując, że to ich wewnętrzna sprawa. W efekcie „wyhodowano” wroga we własnym kraju, który wyraźnie ujawnił się, jak zaczęto likwidować zakłady pracy, a bezrobotnych pozostawiono opiece socjalnej. Błędy w polityce społecznej, odgradzanie się od Innych kulturowo, traktowanie ich jako ludzi drugiej kategorii, zaniedbania w oświacie spowodowały wykorzystywanie opiekuńczego charakteru państwa i wzrost roszczeń wobec władz i społeczeństwa” [Nikitorowicz 2014: 13-14].

Takie stanowisko badacza, teoretyka i kreatora edukacji międzykulturowej w Polsce ściśle koresponduje z założeniami postkolonialno-autochtonicznego paradygmatu badań społecznych nad wielokulturowością w perspektywie pedagogicznej. Łączy je podmiotowość każdego człowieka i każdej kultury, tolerancja i szacunek wobec niej okazywane przez Innych, eksponowanie tożsamości kulturowej, różnorodności i dialogu. Jednak okazuje się, że te piękne idee humanistyczne w rzeczywistym świecie płynnej wielokulturowości w zderzeniu z problemami społecznymi mogą być nadużywane przez ludzi, którym udzielono wsparcia. Wielokulturowość może stać się zatem pielęgnowaną wartością, o ile okaże się w konsekwencji jednością w różnorodności. Wielokulturowość może jednak okazać się także znienawidzonym tyglem, o ile mniejszości zdołają wymknąć się z ram ładu prawnego, społecznego i cywilizacyjnego. Niezbędne jest zatem dziś poszukiwanie nowych koncepcji politycznych i rozwiązań praktycznych trudnych sytuacji wielokulturowości metodami pokojowymi, dialogowymi, demokratycznymi, humanistycznymi. Jedną z takich dróg wskazuje zaangażowany paradygmat postkolonialno-autochtoniczny.

\section{Bibliografia}

Chilisa B. (2012), Indigenous research methodologies, Los Angeles - London - New Delhi Kubinowski D. (2008), Wychowanie i jego konteksty w perspektywie pozapedagogicznej i pedagogicznej, [w:] K. Rubacha (red.), Konceptualizacje przedmiotu badań pedagogiki, Kraków 
Kubinowski D. (2013), Idiomatyczność - synergia - emergencja. Rozwój badań jakościowych w pedagogice polskiej na przełomie XX i XXI wieku, Lublin

Lichtman M. (2006), Qualitative research in education: a user's guide, Thousand Oaks London - New Delhi

Lincoln Y. S., Guba E. G. (2000), Paradigmatic controversies, contradictions, and emerging confluences, [w:] Denzin N. K., Lincoln Y. S. (red.), Handbook of qualitative research (second edition), Thousand Oaks - London - New Delhi

Nikitorowicz J. (2014), Zadania edukacji międzykulturowej w kontekście problemów wielokulturowego świata, „Studia Kulturowo-Edukacyjne” t. IX, nr 1

Sobot K. (2013), Kulturowe uwarunkowania postaw Romów wobec obowiązku szkolnego, Lublin, niepublikowana rozprawa doktorska 


\section{SumMARY}

\section{Postcolonial indigenous paradigm of social research on multiculturalityin pedagogical perspective}

The author shortly presents a new paradigm of social research on multiculturality as called the postcolonial indigenous paradigm. He bases in this presentation on the book by Bagele Chilisa, professor at the University of Botswana who is researcher represented this paradigm and author of methodological monograph under the title Indigenous research methodologies (2012). Postcolonial indigenous paradigm is synergy and transgression of three known paradigms in social sciences as means: critical theory, constructive, and participative ones. The author asks for possibility of using postcolonial indigenous paradigm in social research on multiculturality in Poland. His answer to this question is an exemplification of research project concerning problems of the Roma education in Polish schools. He proposes looking for new political concepts and practical solutions of problems of multiculturality with regards to ideas of postcolonial indigenous paradigm.

Keywords:

postcolonialism, paradigms in social sciences, Roma people 